\title{
The use of Portable X-Ray Fluorescence Spectrometry (PXRFS) for clinical practices
}

\section{${ }^{1}$ Cibele Bugno Zamboni}

Instituto de Pesquisas Energéticas e Nucleares, IPEN - CNEN/SP

Av. Professor Lineu Prestes 2242, 05508-000 São Paulo, SP, Brasil

E-mail: czambonilipen.br

\section{Sabrina Metairon}

Instituto de Pesquisas Energéticas e Nucleares, IPEN-CNEN/SP

Av. Professor Lineu Prestes 2242, 05508-000 São Paulo, SP, Brasil

E-mail: metairon@live.com

\section{Marcia de Almeida Rizzutto; Suene Bernardes dos Santos}

Instituto de Física - Universidade de São Paulo, IFUSP, SP

Rua: do Matão Travessa R 187, 05508-090, São Paulo, SP, Brasil

E-mail: rizzuttodif.usp.br; suenedif.usp.br

In this study the Portable X-Ray Fluorescence Spectrometry performance (PXRFS) was investigated to be used in clinical practices based on data of detection limit, quantification limit and reproducibility for Iron determination in whole blood and serum samples. The Iron concentration's results were compared with NAA data. Using these data the PXRFS performance could be discussed showing to be appropriate for clinical finalities.

X Latin American Symposium on Nuclear Physics and Applications (X LASNPA)

December 1-6 2013

Montevideo, Uruguay

1

Speaker: Cibele Bugno Zamboni 


\section{Introduction}

In the last years the X-ray Fluorescence Technique (EDXRF) has been applied for clinical finality at IPEN/CNEN-SP in collaboration with several research centers from Brazil. These analyses were carried out in an EDXRF Spectrometer at SHIMADZU Co. 720 model Rany $(50 \mathrm{kV}, 100 \mu \mathrm{A}$ - variable, $\mathrm{Rh}$ target) and $\mathrm{Si}(\mathrm{Li})$ detector. There are some advantages for using this technique, once the sample preparation and data analysis have easy and fast procedure as well as low cost [1]. One of the main advantages of using this technique is the procedure established for sample preparation: it eliminates the use of reagent and anticoagulants; offers elemental analysis of blood and/or serum using small quantities $(<0.1 \mathrm{~mL})$ comparatively to conventional analyses performed only in serum (using at least $5 \mathrm{~mL}$ ) [2]. It can also performed simultaneous analysis of elements of clinical relevance (such as: $\mathrm{Cl}, \mathrm{Ca}, \mathrm{Fe}, \mathrm{K}, \mathrm{Mg}$ and others), procedure not possible by the conventional clinical tests [2]. Furthermore, the procedure is non destructive and the samples can be storage without refrigeration. In case of discard, no treatment has to be performed since it can be made as a regular biohazard or by incineration.

In the last years, the use of the EDXRF technique in veterinary medicine, immunology, nutritional and genetic fields, has been done as an alternative for clinical practices with success [3-7]. Now, we intend to optimize the performance of the Energy Dispersive Portable X-Ray Fluorescence Spectrometry (PXRFS) for clinical practices using human whole blood and serum samples. There are several motivations and positive expectations for clinical applications using this portable apparatus. According to the last ProEx (Program External Quality Assessment of clinical laboratories in Brazil, 2012) [8], about 1.4 billion clinical examinations were performed (8 exams per inhabitant/Brazil at a cost of 5 dollars/exam). Of this total, $4 \%$ are biochemical analysis (mainly $\mathrm{Na}, \mathrm{Fe}, \mathrm{Ca}, \mathrm{Cl}$ and $\mathrm{K}$ ). Considering an estimate of an increase of $\sim 2 \%$ of clinical examinations in 2014 provided by ProEx [8] the use of the PXRFS can be an economic alternative for clinical practice, mainly in underserved regions of Brazil (with medical care deficient hospitals).

In this work, we focused on the quantification of Iron in human blood and serum samples for clinical finality. Particularly, Iron deficiency is the most common micronutrient deficiency worldwide, affecting 1.62 billion people ( $25 \%$ of the world population) [9,10]. It is a serious public health issue that affects mainly children, women of childbearing age and elderly individuals. According to the World Health Organization (WHO), Brazil is among the countries of Latin America whose anemia prevalence is considered serious (> 40\%) [10]. The principal goal of this work was to optimize the performance of the Portable X-Ray Fluorescence Spectrometry (PXRFS) for Iron analysis, as well as establish the use of the portable setup to clinical analyses. Iron concentration in whole blood and serum samples of healthy subjects, from São Paulo city (Brazil), were investigated using a compact PXRFS and a comparative analysis with NAA results was outlined. The PXRFS performance was discussed based on these data. 


\section{Experimental}

In this study the biological samples came from Blood Banks of São Paulo city (Brazil): blood donors, age between 25 and 60 years and above of $50 \mathrm{~kg}$. Ten samples were collected in a vacuum plastic tube (without anticoagulants) attached to the donor's arm. Immediately after the collection exactly $100 \mu \mathrm{L}$ of whole blood was transferred to the filter paper (Whatman, $\mathrm{n} \div 41$ ) and dried for few minutes using an infrared lamp. Standardized filter paper provides a quite simple and minimally invasive means for collecting, transporting and storing samples. The biological material, which was in the plastic tube, was then centrifuged and the serum obtained was also transferred to the filter paper following the same procedure. Samples were prepared in duplicate. Standard solution of Iron obtained from high purity metals was prepared following the same procedure (transferred to the filter paper).

The PXRFS analysis was performed using a MINI X spectrometer from Amptek ${ }^{\circledR}$ which is consisted of an Ag X-ray tube and a XR100SDD detector. The characteristics X-ray intensities ( $\mathrm{K}_{\alpha}$ lines) were measured with a Si Drift detector of $25 \mathrm{~mm}^{2}$ x $500 \mu \mathrm{m} / 0.5$ mil) with a Be window of $1.5 "$. The whole blood samples were irradiated for $300 \mathrm{~s}$ and the serum samples for $900 \mathrm{~s}$, both using $30 \mathrm{kV}$ and $5 \mu \mathrm{A}$ excitation conditions. The quantitative analysis was performed using WINAXIL software program.

\section{Results and Discussion}

The Iron concentrations, expressed by median value (MV) and standard deviation (1SD), determined in whole blood and serum samples from PXRF and NAA analyses are presented in Table 1. The results of Detection Limit (DL), Quantification Limit (QL) and the Reference Values (RV) were also presented.

Table 1. Iron concentration values in biological samples

\begin{tabular}{ccc}
\hline Biological material & PXRF & NAA [1] \\
\hline Serum, $\mu \mathrm{g} \mathrm{dL}^{-1}$ & & \\
$\mathrm{MV} \pm 1 \mathrm{SD}$ & $72 \pm 14$ & $65 \pm 9$ \\
$\mathrm{DL}$ & 2.2 & 4.6 \\
$\mathrm{QL}$ & 6.7 & 13.8 \\
$\mathrm{RV}^{*}$ & $44-100$ & $47-83$
\end{tabular}

whole blood, $\mathrm{mgL}^{-1}$ 


$\begin{array}{ccc}\text { MV } \pm 1 \mathrm{SD} & 388 \pm 52 & 409 \pm 53 \\ \mathrm{DL} & 7.5 & 22.1 \\ \mathrm{QL} & 22.7 & 67.0 \\ \mathrm{RV} * & 284-492 & 303-515 \\ * \text { confidence interval of } 95 \% \text { usually adopted for clinical practices }\end{array}$

According to this table the results for serum and whole blood from PXRFS analyses are in agreement with NAA [1], considering a confidence interval of $95 \%( \pm 2 \mathrm{SD})$. For an illustrative visualization the Iron concentration's result in serum and whole blood samples, respectively, are showed in Figures 1 and 2. The confidence intervals adopted are from conventional analyses [2].

Figure 1: Comparative Iron concentration values on serum samples by NAA and PXRF techniques.

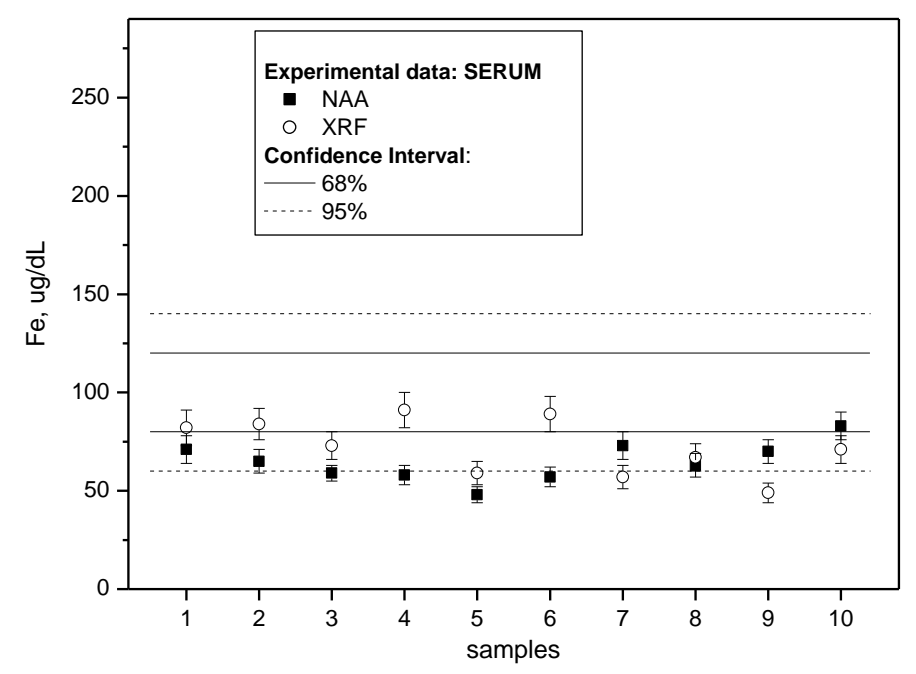

Figure 2: Comparison of Iron concentration values on whole blood samples by NAA and XRF techniques. 


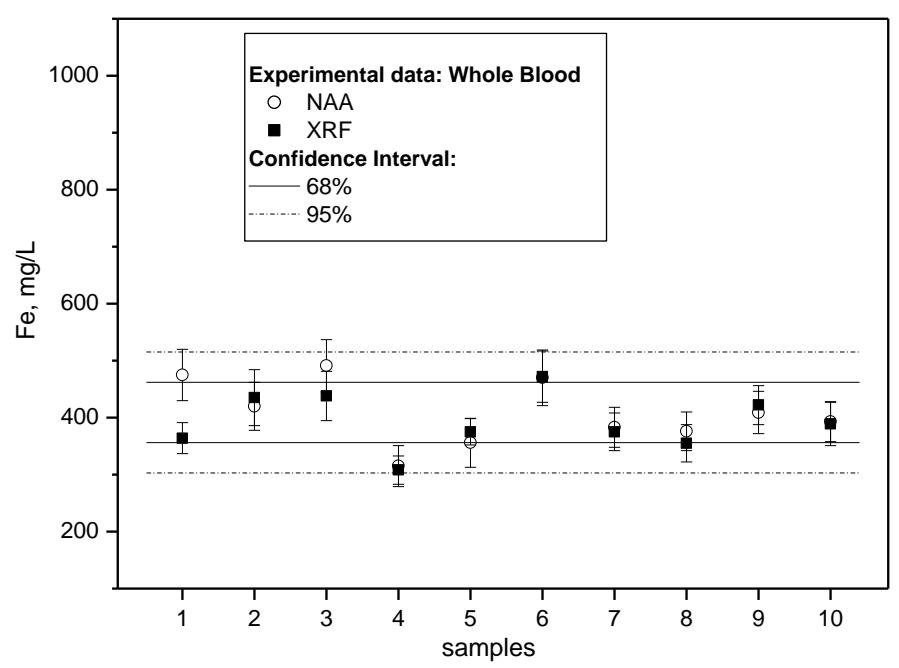

These data suggest that the compact spectrometer can be used to perform Iron analysis for clinical finality. This apparatus has also potential use for other applications, such as: clinical practice performed in premature infants when the biological material is scarce (blood collection for laboratory tests in pediatric practice are the main causes of transfusions in premature infants) [1] and to investigate blood of patients submitted a dialysis treatment [11]. According to Nephrology Brazilian Society, nowadays there are 687 units of Hemodialysis, around 90000 patients performed clinical tests in blood $(\mathrm{Na}, \mathrm{Cl}, \mathrm{K}$ and $\mathrm{Mg}$, before and after dialysis, and $\mathrm{Ca}$ and Fe monthly) [12]. These needs have motivated us to continue this investigation. In the next step, we intend to optimize this spectrometer to analyze other relevant elements in clinical practice, such as: $\mathrm{Ca}, \mathrm{Cl}$ and $\mathrm{K}$.

\section{Conclusion}

The small portable spectrometer (PXRFS) showed to be appropriate for Iron in whole blood and serum analyses with advantages comparatively to the conventional procedure, once it is not necessary to use specifics reactants (important for routine work), it is non destructive and the samples can be storage without refrigeration.

The viability of using this portable instrument can be an economic alternative for clinical practice, mainly in underserved regions of Brazil with medical care deficient hospitals.

\section{Acknowledgement}

The authors would like to acknowledge the Conselho Nacional de Desenvolvimento Científico e Tecnológico (CNPq), Fundação de Amparo a Pesquisa do Estado de São Paulo (FAPESP) and Instituto de Pesquisas Energéticas e Nucleares (IPEN) for the financial support. 


\section{References}

[1] C. B. Zamboni, S. Metairon, M. A. Rizzutto, S. Bernardes, M.R.A. Azevedo, New Trends for Radiation Applications in Medicine, In: Proceedings of Symposium sitting of new nuclear power plants and irradiated fuel facilities, June 24-28, Argentina, (2013)

[2] J. B. Henry, Diagnósticos Clínicos e Tratamento por Métodos Laboratoriais, $19^{\text {ed }}$ Manole, São Paulo \& Brasil (1999).

[3] L. Kovacs, C. B. Zamboni, L. C. Oliveira, V. L. R. Salvador, I. M. Sato, M. R A. Azevedo, Analysis of serum and whole blood using NAA and EDXRF techniques for clinical investigation, In Proceedings of: MTAA-12 Tokyo, Japan (2007)

[4] T.S. Baptista, M.M. Redígolo, C.B. Zamboni, I.M. Sato, Jr. Marcelino, Comparative study of inorganic elements determination in whole blood from Crioula breed horse by EDXRF and NAA analytical techniques, J Radioanal Nucl Chem, 291, 399- 403, (2012)

[5] I.M. Sato, C.B. Zamboni, D.G.L. Oliveira, A.M. Chudzinski-Tavassi, S.M. Simons Investigation of inorganic elements in saliva from amblyomma cajannense species from Brasil by the EDXRF technique, In: Fifth International Congress of the Federation of the European Societies for Trace Elements and Minerals - FESTEM, Avignon, 1, 65, (2013)

[6] M.M. Redígolo, I.M. Sato,; S. Metairon, C.B. Zamboni,. Comparative study of inorganic elements determination in whole blood from Dmd $d^{m d x} / J$ mice strain by EDXRF and NAA analytical techniques. In: Fifth International Congress of the Federation of the European Societies for Trace Elements and Minerals - FESTEM, Avignon, 1, 71, (2013)

[7] M.M. Redígolo, R.O. Aguiar, C.B. Zamboni, I.M. Sato, Determination of reference interval values for inorganic elements in whole blood samples of humans and laboratory animals by X-ray fluorescence spectrometry, J Radioanal Nucl Chem, 297, 463-467, (2013)

[8] ProEx (2013) http:// www.pncp.org.br . Accessed 13 Sep 2013

[9] R. Stoltzfus, Defining iron-deficiency anemia in public health terms: a time for reflection, $J$ Nutr, 131:565S-567, (2001)

[10] B. Benoist, E. McLean, I. Egli, M. Cogswell, Worldwide prevalence of anemia 1993-2005: WHO global database on anemia, Geneva: World Health Organization, (2008)

[11] S. Metairon, C. B. Zamboni, L. Kovacs, F. Genezi, N.F. Santos, E.C. Vilela, Analysis of elements in human blood of patients with chronic kidney disease using neutron activation analysis, J Radioanal Nucl Chem, 282: 81-84, (2009)

[12] Resolução - RDC No 15415 junho (2004), http://elegis.anvisa.gov.br/leisref/public/showAct.php?id=11539 Accessed 27 Sept 2013 